\title{
Randomised crossover trial of tripotassium dicitrato bismuthate versus high dose cimetidine for duodenal ulcers resistant to standard dose of cimetidine
}

\author{
S K LAM, N W LEE, J KOO, W M HUI, K H FOK, AND M NG \\ From the Combined Gastrointestinal Unit, Departments of Medicine and Surgery, University of Hong Kong, \\ Queen Mary Hospital, Hong Kong
}

SUMmARY Of 212 patients with duodenal ulcer treated with four weeks of one gram daily cimetidine, 25 had ulcers which underwent no reduction in size despite treatment. The effects of tripotassium dicitrato bismuthate (TDB) tablet four times a day or cimetidine $1.6 \mathrm{~g}$ daily on the healing of these cimetidine resistant ulcers were compared in a randomised crossover trial. Ten of 12 patients on tripotassium dicitrato bismuthate and five of 13 patients on high dose cimetidine had complete healing $(p<0.02)$. On crossing over, seven of the eight ulcers not healed by high dose cimetidine completely healed with TDB in another four weeks, and one of the two ulcers not healed by TDB healed with high dose cimetidine. Overall, TDB healed $85 \%$ of cimetidine resistant ulcers, whereas high dose cimetidine healed $40 \% \quad(\mathrm{p}<0.006)$. Tripotassium dicitrato bismuthate is recommended for cimetidine resistant duodenal ulcers.

Approximately $70 \%$ of duodenal ulcers would heal after four to six weeks of one gram daily cimetidine. 12 There are no clear guidelines for the management of the cimetidine non-responders. Further cimetidine treatment for four to eight weeks may heal another 5-20\% of patients. ${ }^{3}$ Switching over to ranitidine, a newer and more potent $\mathrm{H}_{2}$-receptor antagonist, has been reported with some success, ${ }^{+}$but the evidence is not clear as the studies were not controlled. Surgery thus appears to be a reasonable treatment and is frequently advised.

Controlled trials have shown that the colloidal bismuth. tripotassium dicitrato bismuthate (TDB), also heals approximately $70 \%$ of patients with duodenal ulcer." Although the exact mechanism of healing is unknown. TDB has been shown to adhere preferentially to the ulcer base. ${ }^{6}$ and thereby exists a local action.

The aim of this study is to compare, using a randomised, controlled, crossover method, the efficacy of an increased dose of cimetidine vs TDB tablets, which are more palatable than the TDB liquid. in the healing of duodenal ulcers resistant to the standard dose of cimetidine.

Address for correspondence: Dr S K Lam. Department of Medicine. University of Hong Kong. Queen Mary Hospital. Hong Kong.

Received for publication 8 August 1983

\section{Methods}

PATIENTS

A duodenal ulcer is considered to be resistant to cimetidine ( $200 \mathrm{mg}$ three times a day and $400 \mathrm{mg}$ at bedtime), if at the end of four weeks of treatment its longest diameter as observed endoscopically has decreased by less than $25 \%$, remained unchanged, or become bigger. The $25 \%$ limit was accepted because of the known variability of endoscopic estimation of ulcer size. Twenty five patients whose duodenal ulcers fit into these criteria were recruited from among 212 cimetidine treated patients. There were 17 men with a mean age of 48.0 years (range 21-65 years) and eight women with a mean age of 41.9 years (range 18-55 years). They did not have previous gastric surgery nor did they have any concommitant major medical problem such as cardiac, pulmonary, hepatic, or renal insufficiencies. None had a fasting serum gastrin concentration in the range of the Zollinger-Ellison syndrome.

\section{TRIAL DESIGN}

A series of new patients with endoscopically proven duodenal ulcer attending the ulcer clinic of the combined gastrointestinal unit underwent a programme which included a detailed recording of their clinical features, personal habits, and endo- 
scopic characteristics, ${ }^{7}$ as well as a two morning physiological measurement of their basal acid output, pentagastrin stimulated maximal acid output, pentagastrin $D_{50}$ - that is, dose responsible for half maximal acid output derived from a dose response curve, ${ }^{8}$ fasting serum gastrin, and integrated gastrin response to a standard meal, ${ }^{9}$ in addition to routine haematology, biochemistry, and blood group. Caution was taken to stop such drugs as anticholinergices or $\mathrm{H}_{2}$-receptor antagonists for at least 72 hours before the physiological tests. They were treated with cimetidine $200 \mathrm{mg}$ three times a day with meals and $400 \mathrm{mg}$ at bedtime, and were reendoscoped at the end of four weeks. Drug compliance was checked by counting the returned drugs.

Thus the 25 patients underwent an initial endoscopy and the above tests, were then given the standard dose of cimetidine at the ulcer clinic for four weeks, and were found afterwards at reendoscopy to have a resistant duodenal ulcer. Their drug compliance for cimetidine was $94 \cdot 6 \pm 0 \cdot 5 \%$. They were then randomised to either (1) tripotassium dicitrato bismuthate (Gist Brocades), one tablet to be chewed and swallowed half an hour before breakfast, lunch, and supper, and at bedtime, or (2) cimetidine (Smith, Kline \& French Laboratories) orally $400 \mathrm{mg}$ three times a day with meals and $400 \mathrm{mg}$ at bedtime. Endoscopy was again performed after four weeks of outpatient treatment. If the ulcer was healed - that is, its base completely disappeared with or without residual inflammation (usually hyperaemia or granularity) the study was ended. If the ulcer was not healed, the patient was crossed over to the other form of treatment for another four weeks, and reassessed subsequently by endoscopy. No other medications were given during the study period. Compliance was ascertained by recording the number of any remaining tablets in the returned bottle at the end of each treatment period. Each patient was given a diary card, on which the number of day time and night time pain episodes and their severity (mild, moderate, or severe) were recorded.

The endoscopist was not aware of the clinical data and any previous endoscopy results. The longest diameter was estimated using the tips of the biopsy forceps. Each patient was examined by the same endoscopist throughout the study.

Analysis of variance and $\chi^{2}$ test with Yate's correction ${ }^{10}$ were used, and $p$ values of less than 0.05 were considered significant.

\section{Results}

There were no significant differences between the
TDB treated and cimetidine treated patients with respect to the clinical, personal, physiological, and endoscopic characteristics listed in Table 1. No patient defaulted, and drug compliance was $91.8 \pm 0.5 \%$ and $93.2 \pm 0.4 \%$ respectively for the TDB groups and the cimetidine group. Compared with cimetidine, TDB resulted in significantly more healing but not symptomatic improvement in the initial four weeks of treatment and in the overall assessment after eight weeks of treatment (Table 2).

\section{Discussion}

Previous reports on cimetidine non-responders did not specify whether the ulcer size remained stationary despite treatment. ${ }^{3}$ It is possible that some of these ulcers became smaller at the end of the short term treatment, and should be more appropriately called slow responders. This study reports a series of duodenal ulcers the size of which remained unchanged after four weeks of one gram daily cimetidine; the mean ulcer diameter was in fact slightly larger afterwards. This series, therefore, are more likely to represent the truly cimetidine resistant ulcers. Such ulcers are uncommon and occurred in $11.8 \%$ of our duodenal ulcer population.

Increasing the dose of cimetidine to $1.6 \mathrm{~g}$ daily healed only about $40 \%$ of such cimetidine resistant ulcers, whereas the use of TDB tablets healed over $80 \%$. The results of the subsequent crossover study further supports the efficacy of TDB, which again healed over $80 \%$ of the patients who did not respond to high dose of cimetidine. Overall, TDB achieved over $85 \%$ of success in cimetidine resistant patients, whereas increasing the dose of cimetidine achieved only about $40 \%$, and the difference was statistically significant. It is to be noted that $1.6 \mathrm{~g}$ daily cimetidine is a particularly high dose for Chinese patients, since $0.5 \mathrm{~g}$ daily dose was shown to have identical acid inhibition and efficacy as the $1 \mathrm{~g}$ daily dose in these patients. ${ }^{11}$

Short term TDB is known to heal approximately $70 \%$ of duodenal ulcers. ${ }^{5}$ The effectiveness of TDB in cimetidine resistant ulcers as shown in this study has important implications. Firstly, this suggests that acid inhibition is not important in the healing of such ulcers, as they represent cimetidine failures and TDB is not an antacid. Tripotassium dicitrato bismuthate forms a microscopic layer of bismuth which adheres to the base of an ulcer for at least six hours, and attracts a large influx of macrophages to the ulcer edge. ${ }^{6}$ The bismuth layer may insulate the ulcer from the aggressive peptic force in the bowel lumen. The role of the macrophages, which are 
Table 1 Characteristics of patients treated with tripotassium dicitrato bismuthate (TDB) and cimetidine tablets

\begin{tabular}{|c|c|c|c|}
\hline & $T D B$ & $\begin{array}{l}\text { Cimetidine } \\
1.6 \text { g/day }\end{array}$ & $p<$ \\
\hline Patient no & 12 & 13 & \\
\hline Male, \% & $75 \cdot 0$ & $61 \cdot 5$ & 0.6 \\
\hline Age, yr & $50 \cdot 2 \pm 3 \cdot 0$ & $41 \cdot 9 \pm 4 \cdot 7$ & $0 \cdot 2$ \\
\hline Age of onset of symptoms, yr & $39 \cdot 4 \pm 2 \cdot 3$ & $34 \cdot 5 \pm 4 \cdot 8$ & $0 \cdot 6$ \\
\hline Early onset age $(<30 \mathrm{yr}),{ }^{14} \%$ & $33 \cdot 3$ & $38 \cdot 5$ & $0 \cdot 6$ \\
\hline Duration of symptoms, yr & $10 \cdot 6 \pm 2 \cdot 6$ & $7 \cdot 0 \pm 1 \cdot 6$ & $0 \cdot 2$ \\
\hline Gastrointestinal bleeding, $\%$ & $41 \cdot 7$ & $46 \cdot 1$ & $0 \cdot 6$ \\
\hline Family history of dyspepsia, \% & $33 \cdot 3$ & $46 \cdot 1$ & $0 \cdot 5$ \\
\hline Blood group $\mathrm{O}, \%$ & $33 \cdot 3$ & $46 \cdot 1$ & $0 \cdot 5$ \\
\hline Cigarette smokers, \% & $66 \cdot 7$ & $53 \cdot 8$ & $0 \cdot 5$ \\
\hline$>20$ cigarettes $/$ day, $\%$ & $58 \cdot 3$ & $38 \cdot 5$ & $0 \cdot 3$ \\
\hline Alcohol users, \% & $25 \cdot 0$ & $15 \cdot 4$ & $0 \cdot 5$ \\
\hline$>50 \mathrm{~g}$ alcohol $/$ day. $\%$ & $16 \cdot 7$ & $15 \cdot 4$ & $0 \cdot 6$ \\
\hline Analgesic users, $\%$ & $8 \cdot 3$ & $7 \cdot 7$ & $0 \cdot 5$ \\
\hline Basal acid output, $\mathrm{mmol} / \mathrm{h}$ & $2 \cdot 3 \pm 0 \cdot 7$ & $3 \cdot 1 \pm 0 \cdot 8$ & $0 \cdot 5$ \\
\hline Maximal acid output, $\mathrm{mmol} / \mathrm{h}$ & $25 \cdot 7 \pm 3 \cdot 1$ & $27 \cdot 4 \pm 2 \cdot 7$ & 0.7 \\
\hline $\mathrm{mmol} / \mathrm{h} / \mathrm{kg}$ & $0.45 \pm 0.05$ & $0.54 \pm 0.06$ & $0 \cdot 2$ \\
\hline Hypersecretors $(>0.45 \mathrm{mmol} / \mathrm{h} / \mathrm{kg}),{ }^{15} \%$ & $50 \cdot 0$ & $61 \cdot 5$ & 0.5 \\
\hline$D_{50}$ (corrected for basal acid), $\mathrm{ng} / \mathrm{kg} / \mathrm{h}$ & $145 \pm 44$ & $119 \pm 32$ & 0.7 \\
\hline Fasting serum gastrin, $\mathrm{nmol} / \mathrm{l}$ & $40 \cdot 2 \pm 5 \cdot 5$ & $50 \cdot 1 \pm 7 \cdot 5$ & 0.6 \\
\hline Postprandial serum gastrin, $\mathrm{nmol} / \mathrm{min} / \mathrm{l}$ & $10 \cdot 8 \pm 1 \cdot 4$ & $10 \cdot 0 \pm 1 \cdot 4$ & $0 \cdot 7$ \\
\hline Pain free before treatment, $\%$ & $23 \cdot 1$ & $30 \cdot 8$ & 0.5 \\
\hline \multicolumn{4}{|l|}{ Longest ulcer diameter, mm } \\
\hline Before standard dose of cimetidine & $7 \cdot 8 \pm 1 \cdot 4$ & $7 \cdot 5 \pm 0 \cdot 9$ & $0 \cdot 8$ \\
\hline Before randomisation & $8 \cdot 3 \pm 0 \cdot 9$ & $8 \cdot 7 \pm 1 \cdot 1$ & 0.8 \\
\hline
\end{tabular}

known to be important in wound healing, ${ }^{12}$ is as yet unknown. The exact mechanism of TDB in ulcer healing deserves further investigation.

Secondly, this study also suggests that cimetidine resistant duodenal ulcers may be regarded as a subgroup of duodenal ulcers with separate pathophysiology. It is now generally recognised that the physiologic abnormality of duodenal ulcer is heterogeneous. ${ }^{13}$ We have reported in a separate paper that patients whose ulcers do not heal by standard doses of cimetidine are more often cigarette

Table 2 Comparison of the efficacy of tripotassium dicitrato bismuthate $(T D B)$ and high dose cimetidine in the treatment of duodenal ulcers resistant to standard dose of cimetidine

\begin{tabular}{llll}
\hline & $\begin{array}{l}\text { TDB } \\
\text { tablets }\end{array}$ & $\begin{array}{l}\text { Cimetidine } \\
1 \cdot 6 \text { g/day }\end{array}$ & $p<$ \\
\hline Initial treatment, no & 12 & 13 & \\
Healed, no (\%) & $10(83 \cdot 3)$ & $5(38 \cdot 5)$ & $0 \cdot 02$ \\
Pain free week 1 (\%) & $50 \cdot 0$ & $46 \cdot 1$ & 0.66 \\
$\quad$ week 4 (\%) & 83.3 & 76.9 & 0.52 \\
Crossover, no & 8 & 2 & \\
Healed, no (\%) & $7(87 \cdot 5)$ & $1(50 \cdot 0)$ & $0 \cdot 21$ \\
Pain free week 4 (\%) & $87 \cdot 5$ & $50 \cdot 0$ & $0 \cdot 21$ \\
Overall, no & 20 & 15 & \\
Healed, no (\%) & $17(85 \cdot 0)$ & $40 \cdot 0$ & 0.006 \\
\hline
\end{tabular}

smokers who smoke more heavily, have more pentagastrin sensitive parietal cells, and have more apical ulcers and bigger ulcers than those whose ulcers heal after four weeks of treatment. ${ }^{7}$

The authors are grateful to $\mathrm{M}$ Chong and $\mathrm{B} \mathrm{Ng}$ for nursing assistance, to $P$ Yip and $G \mathrm{H}$ Joe for technical support, and to J Watt for secretarial help. This study is supported in part by research grants $355 / 041 / 0006,311 / 030 / 8010,311 / 030 / 8009$, University of Hong Kong.

\section{References}

1 Winship DH. Cimetidine in the treatment of duodenal ulcer. Review and commentary. Gastroenterology 1978; 74: 402-6.

2 Misiewicz JJ. Histamine $\mathrm{H}_{2}$-receptor antagonists in short- and long-term treatment of duodenal ulcer. In: Holtermuller KH, Malagelada JR, eds. Advances in ulcer disease. Amsterdam, Oxford, Princeton: Excerpta Medica, 1980: 318-29.

3 Bardhan KD. Non-responders to cimetidine treatment, part 2. In: Baron $\mathrm{JH}$, ed. Cimetidine in the 80s. Edinburgh: Churchill Livingstone, 1981: 42-57.

4 Mohammed R, Mitchell K, Mackay C. The treatment of cimetidine-resistant peptic ulcers with ranitidine 
hydrochloride. In: Misiewicz JJ, Wormsley KG, eds. The clinical use of ranitidine. Oxford: Medicine Publishing Foundation, 1981: 251-3.

5 Lam SK, Koo J. New approach with old medicine: antacids and bismuth. In: Pfeiffer CJ, ed. Drugs and peptic ulcer. Florida: CRC Press, 1982: 159-82.

6 Koo J, Ho J, Lam SK, Wong J, Ong GB. Selective coating of gastric ulcer by. tripotassium dicitrato bismuthate in the rat. Gastroenterology 1982; 82: 864-70.

7 Lam SK, Koo J. Accurate prediction of duodenal-ulcer healing rate by discriminant analysis. Gastroenterology 1983; 85: 403-12.

8 Lam SK, Isenberg JI, Grossman MI, Lane WH, Walsh $\mathrm{JH}$. Gastric acid secretion is abnormally sensitive to endogenous gastrin released after peptone test meals in duodenal ulcer patients. J Clin Invest 1980; 65: 555-62.

9 Lam SK, Ong GB. Relationship of postprandial serum gastrin response to sex, body weight, blood group status, familial dyspepsia, duration, and age of onset of ulcer symptoms in duodenal ulcer. Gut 1980; 21: 528-32.
10 Snedecor GW, Cochran WG. Statistical methods. 6th ed. Ames, Iowa: Iowa State University Press, 1967.

11 Lam SK, Koo J. Effective healing of duodenal ulcer in Chinese patients with half gram daily cimetidine and prediction of healing and non-healing by discriminant analysis. Gastroenterology 1982; 82: 1108.

12 Peacock EE, Van Winkle W. Surgery and biology of wound repair. Inflammation and cellular response to injury. Philadelphia, London, Toronto: W B Saunders, 1970: 8-12.

13 Lam SK. Physiọlogic abnormalities and heterogeneity in peptic ulcer. In: Rotter JI, Samloff IM, Rimoin DL, eds. The genetics and heterogeneity of common gastrointestinal disorders. New York: Academic Press, 1980: 67-80.

14 Lam SK, Ong GB. Duodenal ulcers: early and late onset. Gut 1976; 17: 167-79.

15 Lam SK, Hasan M, Sircus W, Wong J, Ong GB, Prescott RJ. Comparison of maximal acid output and gastrin response to meals in Chinese and Scottish normal and duodenal ulcer subjects. Gut 1980; 21: 324-8. 